METALLURGY AND FOUNDRY ENGINEERING - Vol. 36, 2010, No. 2

\author{
Grzegorz Piwowarski*, Witold K. Krajewski***, Janusz Lelito**
}

\title{
OPTIMIZATION OF CASTING TECHNOLOGY OF THE PRESSURE DIE CAST AZ91D MG-BASED ALLOY
}

\section{INTRODUCTION}

Pressure die casting has been under constant development since its beginnings. New materials are used in the manufacturing of castings, which means that technologies develop. Undoubtedly, the greatest technological change, especially when it comes to the design of pressure machines, was the division of the metal injection cycle into the mould cavity into three phases. As a result, the quality seen in the manufactured details has considerably increased [1].

The pressure die casting process, due to the costs of preparing the production technology, and in particular the cost of mould manufacturing, requires a specific approach already in the early stages of production, which limits the ability to introduce any major changes to a ready mould. And so, if the used technology is failing, it is necessary to manufacture entire new moulds or at best only their inner pads, which increases the cost significantly. However, the development of information technologies made it possible for engineers to carry out trials of casting a given detail on virtual models in a computer memory. These trials do not generate costs and create an opportunity to assess both the parameters of the casting process and the quality of the manufactured cast. In addition, it is possible to optimize the casting technology during its designing stages hence improving one or more figures of merit. This process has been considerably improved thanks to the employment of numerical methods and computer simulations that are based on these methods. Significant progress in the area of computer simulation of casting processes was made in the late 1980s.

The first simulation programmes were based on simple forms of the Fourier-Kirchhoff equation and were only capable of describing, in a simplified manner, the flow of heat in the cast-mould system. These programmes did not take into account the movement of metal

* M.Sc., ** Ph.D., *** Ph.D., D.Sc.: Faculty of Foundry Engineering, AGH University of Science and Technology, Kraków, Poland; e-mail: krajwit@agh.edu.pl 
during the process of casting the mould cavity. It is easier to simulate thermal processes than it is to simulate the flow of metal in the mould with a simultaneous heat exchange. The latter takes more time and is more complicated, and so the process was realized with the construction of adjoint models, which, when operating, make use of the so-called temperature maps. These maps are based on the initial conditions of solidification and on the course of solidification itself [2].

\section{RESEARH METHODOLOGY}

\subsection{Research materials}

A cast made of alloy AZ91D, manufactured using the pressure technology on a machine with a hot pressing chamber was the subject of this research. The simulation of the process of casting the mould cavity with a liquid magnesium alloy, and the process of solidification and self-cooling of the filled cavity, was performed using the MAGMASoft software.

Table 1. Chemical composition [wt \%] of alloy AZ91D [3]

\begin{tabular}{|c|c|c|c|c|c|c|c|c||}
\hline $\begin{array}{c}\text { Al. } \\
\%\end{array}$ & $\begin{array}{c}\mathrm{Mn} \\
\%\end{array}$ & $\begin{array}{c}\mathrm{Zn} \\
\%\end{array}$ & $\begin{array}{c}\mathrm{Si} \max \\
\%\end{array}$ & $\begin{array}{c}\mathrm{Cu} \max \\
\%\end{array}$ & $\begin{array}{c}\mathrm{Ni} \max \\
\%\end{array}$ & $\begin{array}{c}\text { Fe max } \\
\%\end{array}$ & $\begin{array}{c}\mathrm{Be} \\
\%\end{array}$ & $\begin{array}{c}\text { Inne } \\
\max , \%\end{array}$ \\
\hline $8.5-9.5$ & $0.17-0.3$ & $0.45-0.9$ & 0.05 & 0.025 & 0.001 & 0.004 & $0.0005-0.0015$ & 0.01 \\
\hline
\end{tabular}

Alloy AZ91D (Tab. 1) is the most popular magnesium alloy used in die casting due to its good casting, physical, and endurance qualities. It is especially important to emphasize its relatively good castability and corrosion resistance. As always, when dealing with magnesium alloys, one must exercise caution during the melting process and during the preparation of liquid metals. Magnesium has a high affinity for oxygen and as such, in a liquid state, undergoes violent oxidation. Therefore, one should use protective atmosphere technology that prevents liquid metals from coming into contact with oxygen.

\subsection{Process preparation}

The first stage that led to the simulation of pressure casting was collecting all the parameters necessary to perform the simulation. Among those parameters are: the type of pressure machine, the grade of alloy and its temperature, and the plunger travel velocity in all phases of mould casting. The time it takes to perform individual cycle operations such as assembling half moulds, moving slides, removing movable mould parts, or applying release agents is an important factor. The next stage is based on the preparation of the casting model and also of the mould model. Normally, it is possible to receive the whole mould solid from the designer, but then it needs to be optimized (the number of components is reduced), which considerably affects the time necessary to make numerical calculations. If the given parts are manufactured using the same materials, and they fit closely together, it means they can be treated as a one solid shape, because the way with which they conduct heat remains 
the same. Cooling channels and vents constitute an important part of the mould, therefore it is crucial to pay close attention to the way they are reproduced in virtual models as well. All modelling geometries are saved in the STL binary format and once all necessary parameters are gathered and all models are properly prepared, all that data is loaded into the simulation programme. Reading the STL files into the simulation programme is the initial part of the preparation, leading towards the actual simulation. The recorded items are instantly labelled with the type of material and it is determined whether the given solid is a movable part or not, whether it is a slide, a cooling channel, or a half-mould. After all the items are placed in the preprocessor, the created geometry is saved. Then the number and placement of the combined cells and the grid cells that create thin walls is monitored, as these walls are unfavourable and need to be eliminated. In the manufactured cast there was a rather large number of thin walls, which, for example, were created by connections between castings and overflows. The elimination process is achieved with the help of "grid densification". This works by finding the coordinates of such a locked cell. The collected coordinates are saved in a CMD file, which is then moved, along with the previously created mould grid, to the preprocessor and all the changes made are saved. Once the grid cohesion is checked, the relevant measuring points and tracers are set. It is then possible to start the actual simulation process.

The computational process may take from a few up to a several dozen of hours, as it depends not only on the computing power of the computer's processor, but also on the size of the casting, and its level of complexity. This is dictated by the fact that the data, which is eventually presented by the programme, is a result of carrying out several dozens of casting cycles. During these cycles the thermal parameters of the mould are as close to the real ones as possible, that is, the area of the mould, which comes directly into contact with metal, was already heated up a few times during the casting of an alloy, and cooled down when both cooling and release agents were sprayed over it. Only in such stabilized conditions is it feasible to achieve optimally accurate results.

\section{RESULTS}

Modelling was carried out for two widths of a pouring slot. The first simulation was performed for a $1 \mathrm{~mm}$ wide pouring slot. The evaluation of the results is conclusive and it states that the metal flow velocity in that particular spot was too high. With the plunger velocity of the pressure machine amounting to $4 \mathrm{~m} / \mathrm{s}$, the velocity in the pouring slot reached around $220 \mathrm{~m} / \mathrm{s}$. The influence of such a velocity is highly unfavourable, not only because of the parameters of the obtained casting, but also because of the negative effect it has on the mould, causing substantial erosion. The second parameter that was taken into consideration was how air evacuation from the mould cavity was organized. In the virtual computational environment, air escaped through cylinder-shaped channels, with their cross-sectional area being equal to the area of gaps between the actual parts of the mould. The results achieved in this simulation in the $215^{\text {th }}, 223^{\text {rd }}, 230^{\text {th }}$, and $245^{\text {th }}$ millisecond of the cycle respectively, are presented in Figure 1. 
a)

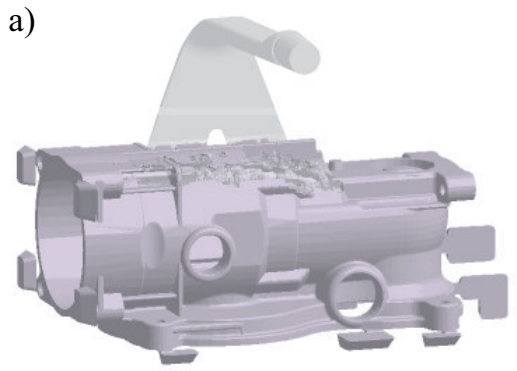

c)

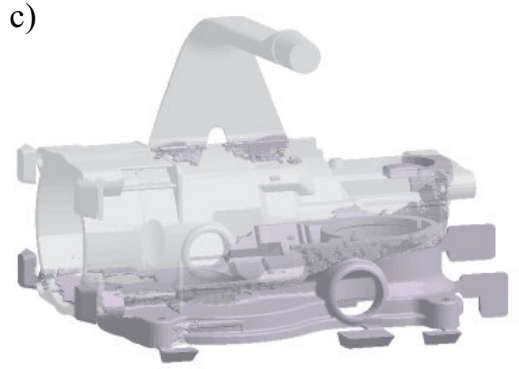

b)

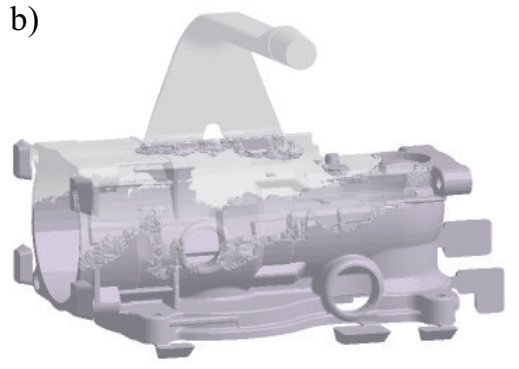

d)

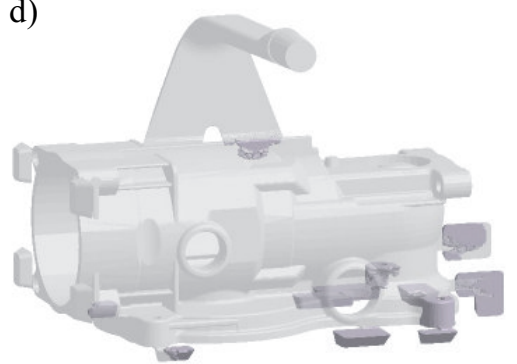

Fig. 1. Air evacuation from the mould cavity in the a) $215 \mathrm{~ms}$; b) $223 \mathrm{~ms}$; c) $230 \mathrm{~ms}$ and d) $245 \mathrm{~ms}$ of the cycle

The large amount of metal spraying that appears after it travels through the pouring slot causes the air not only to be captured within the volume of the flowing metal, between the mould wall and the core, but also to be unevenly evacuated from the mould cavity. This leads to a situation where the obtained casting has defects in the form of misruns and porosity. Areas that are especially exposed to such defects are presented in Figure 2 (the brighter spots represent empty spaces).

In the second simulation all the process parameters were the same as in the first one, apart from the width of the pouring slot, which was altered from $1 \mathrm{~mm}$ to $1.4 \mathrm{~mm}$. The first significant difference was the reduced flow velocity of the liquid metal through the pouring slot. The plunger velocity was left unchanged, however, the metal flow velocity in the pouring slot dropped to around $98 \mathrm{~m} / \mathrm{s}$. As a result, the metal spraying was limited, in comparison to the first case, and the mould was cast with a compact metal flow. Air evacuation from the mould cavity was also affected, since the more compact metal flow does not lead to the air being trapped inside the metal's volume. The metal flow works like a piston that gradually pushes the air outside. The air evacuation process from the mould cavity is illustrated in Figure 3 during the $215^{\text {th }}, 223^{\text {rd }}, 230^{\text {th }}$, and $245^{\text {th }}$ millisecond of the cycle respectively. After comparing Figure 1 with Figure 3, one can observe, especially during the $245 \mathrm{~ms}$ of the cycle, that there are no empty spaces left within the casting volume where air could be trapped. In Figure 3, in the $245^{\text {th }}$ millisecond of the cycle, it can be noticed that the spaces where air could still be trapped are all in the overflows. This is favourable, as risers are cut off and the casting remains flawless. 


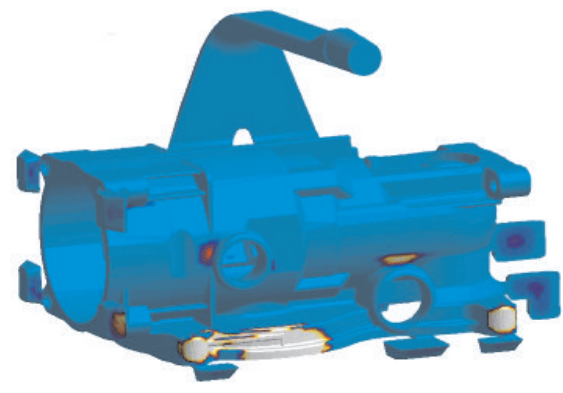

POROSITY

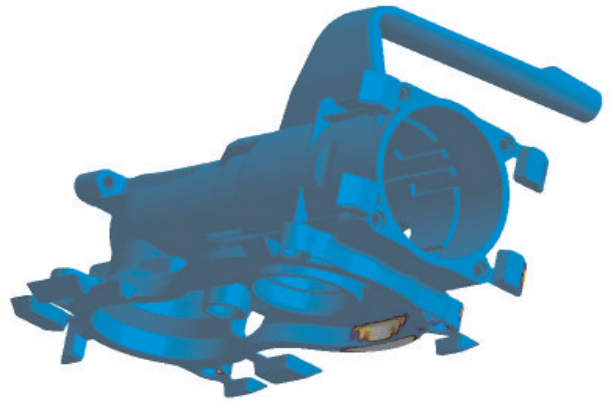

50.0

42.9

35.7

28.6

21.4

14.3

7.1

0.0

Fig. 2. The porosity results in the casting achieved in the first simulation
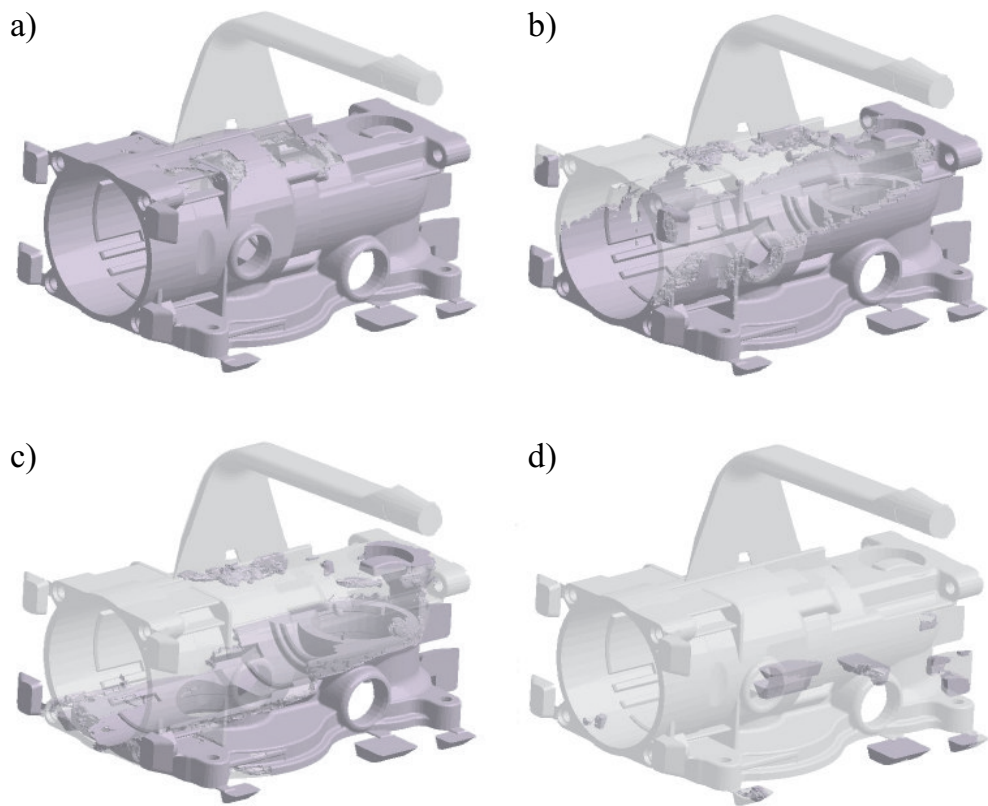

Fig. 3. Air evacuation from the mould cavity in the a) $215 \mathrm{~ms}$; b) $223 \mathrm{~ms}$; c) $230 \mathrm{~ms}$ and d) $245 \mathrm{~ms}$ of the cycle 


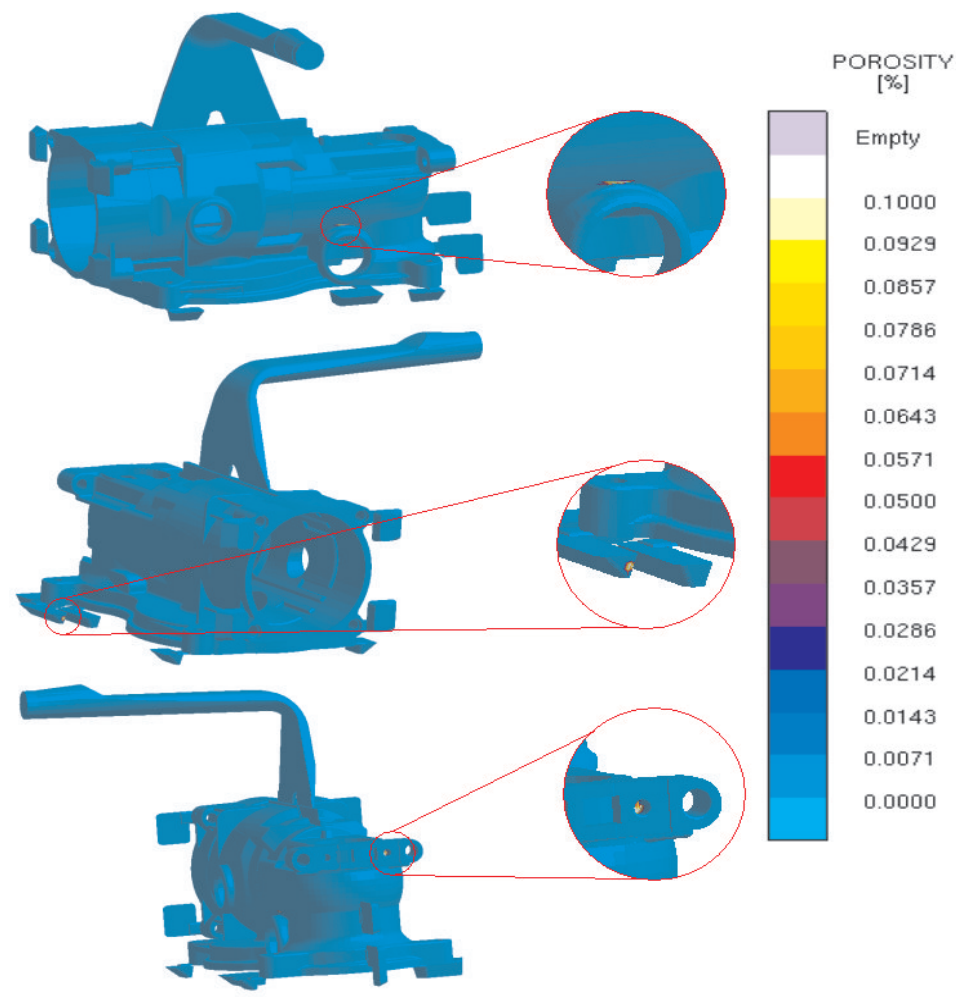

Fig. 4. The porosity results in the casting achieved in the second simulation

After assessing the final parameters, and in particular after taking the porosity into consideration (Fig. 4), it can be said that the specific choice of the pouring slot width, as well as of other parameters, results in obtaining a flawless casting.

\section{CONCLUSIONS}

The development of computer simulations of casting processes in pressure die casting allows us to probe into the process itself and analyze it step by step on a number of planes and for a number of parameters. In the examined case:

- the overall assessment of process parameters was achieved,

- the weakness in the form of a too narrow pouring slot was discovered,

- all the defects, if they occur, can be expected to be found outside the casting (e.g. in risers).

\section{Acknowledgements}

The authors acknowledge The European Community for financial support under Marie Curie Transfer of Knowledge grant No. MTKD-CT-2006-042468; The University of 
Cambridge - Department of Materials Science and Metallurgy for provision of laboratory facilities; The Clare Hall College - Cambridge University for the stay (WKK) during July/ August 2007/2008/2009/2010 and provision of Internet resources

\section{REFERENCES}

[1] Dańko J.: Maszyny i urządzenia do odlewania pod ciśnieniem, Wydawnictwa Naukowo-Dydaktyczne AGH, Kraków 2000

[2] Ignaszak Z: Virtual prototyping w odlewnictwie. Bazy danych i walidacja, Wydawnictwo Politechniki Poznańskiej, Poznań 2002

[3] http://www.alpha.krakow.pl (10.09.2007)

[4] Piwowarski G.: Optymalizacja technologii wytwarzania odlewu podczas odlewania ciśnieniowego stopów magnezu, AGH, Kraków, Wydział Odlewnictwa, 2008 (praca dyplomowa magisterska)

Received

November 2010 